\title{
PROBLEM-BASED LEARNING TO IMPROVE STUDENTS' GRAMMAR COMPETENCE
}

\author{
Mukminatus Zuhriyah \\ Universitas Hasyim Asy'ari Tebuireng Jombang \\ zoehrea@gmail.com \\ DOI: http://dx.doi.org/10.18326/rgt.v10i1.48-61
}

\section{ENGLISH ABSTRACT}

Grammar becomes one of the subjects studied in all Indonesian English Departments. It is because grammar has the important role in all English skills. Grammar makes those four English skills meaningful. Somebody can be said as a master of English when he or she also masters grammar. Unfortunately, learning grammar is not as easy as what we think. It needs the effective method that can make the learners motivated and active in learning as well as in applying the grammar in the real life. Problem-based learning applied in this research is one of the alternatives that can help the learners learn grammar easily. This research was a collaborative action research whose general purpose to know whether or not Problem-based learning could improve the students' grammar competence. Meanwhile, the specific purposes were to know the lecturer's activities, the students' activities, and the students' responses when problem-based learning was implemented in grammar class. Nine students of the fifth semester of English department of education faculty of Hasyim Asy'ari University (UNHASY) Tebuireng Jombang in the academic year of 2016/2017 became the subjects of this research. The data got was from the observation notes and the grammar test. There was an improvement on students' grammar competence from cycle one to cycle two. It was proven by their mean score from 66.7 in cycle one to 72.8 in cycle two. Meanwhile, the percentage of students passing the minimum mastery criteria was from 44.4 in cycle one and 88.9 in cycle two. So that it can be concluded that problem-based learning could improve students' grammar competence.

Keywords: Problem-Based Learning, Grammar Competence, UNHASY Students

\section{INDONESIAN ABSTRACT}

Grammar merupakan salah satu mata kuliah yang dipelajari seluruh jurusan bahasa Ingggris di Indonesia. Hal ini disebabkan grammar memiliki peranan yang penting dalam semua skill bahasa Inggris. Grammar membuat keempat skill bahasa Inggris tersebut bermakna. Seseorang dikatakan menguasai bahasa Inggris ketika dia juga menguasai grammar. Sayangnya, mempelajari grammar itu tidak semudah yang kita kira. Ini memerlukan metode yang efektif yang mampu membuat mahasiswa termotivasi dan aktif dalam belajar dan begitu pula dalam mengaplikasikannya dalam kehidupan nyata. Problem-based learning yang diaplikasikan dalam penelitian ini merupakan salah satu alternatif yang mampu membantu mahasiswa untuk mempelajari grammar dengan mudah. Penelitian ini adalah penelitian tindakan kelas yang sifatnya kolaboratif yang tujuan umumnya untuk mengetahui apakah problem-based learning mampu meningkatkan kompetensi grammar mahasiswa. Sedangkan 
tujuan khususnya adalah untuk mengetahui aktifitas dosen, aktifitas mahasiswa, dan respon mahasiswa pada saat problem-based learning diaplikasikan di kelas grammar. Sembilan mahasiswa semester lima prodi bahasa Inggris, FIP, Universitas Hasyim Asy'ari (UNHASY) Tebuireng Jombang tahun akademik 2016/2017 menjadi subyek dalam penelitian ini. Data dalam penelitian ini diperoleh dari catatan observasi dan tes grammar. Ada peningkatan kompetensi grammar mahasiswa dari siklus satu ke siklus dua. Ini dibuktikan dari nilai ratarata mereka dari 66.7 di siklus satu menjadi 72.8 di siklus dua. Sedangkan prosentase mahasiswa yang lulus KKM dari 44.4 persen menjadi 88.9 persen. Dengan demikian bisa disimpulkan bahwa problem-based learning mampu meningkatkan kompetensi grammar mahasiswa.

Kata Kunci: Problem-Based Learning , Kompetensi Grammar, Mahasiswa UNHASY

\section{INTRODUCTION}

We all know that all English departments in Indonesian universities always put grammar as one of the subjects in their curriculum that should be taken by the students. Grammar is a very important language component that should be mastered by the English students. It is because grammar has the roles in all language skills. When reading, grammar is needed to understand the content of the reading texts well. When writing, grammar is needed to get understandable writing. It also happens when listening and speaking. It is supported by Mart (2013: 124) who states that understanding grammar is the key in foreign language acquisition. In line with this, Tomakin (2014: 116) states that somebody cannot master a language without learning its grammar because grammar helps him or her to construct meaningful words or sentences. Additionally, Priya (2015: 447) argues that communication becomes coherent and logical by using grammar. Then, Baleghizadeh and Mozaheb (2011: 364) state that the learners' age, their proficiency level, and educational background cause the importance levels of grammar to be different.

It is a fact that learning grammar is not easy. Many students of the fifth semester of English Department of Education Faculty of Hasyim Asy'ari University (UNHASY) often make mistakes in their grammar. It is because the acquisition of grammar itself is related to somebody's cognitive skills (Uibu and Liiver, 2015: 72). Besides, Baleghizadeh and Mozaheb (2011: 364) state that there are some special characteristics to be a teacher of grammar for ESL/EFL learners. According to Lawrence and Lawrence (2013: 66), teaching grammar is not 
the easy work because the teacher of grammar must have the knowledge of grammar and its application.

Based on the preliminary study to the fifth semester students of English Department of Education Faculty of Hasyim Asy'ari University (UNHASY) held on November 7, 2016, the students still had low grammar competence. It could be seen from the score of grammar which they got. Their mean score was 65 . The highest score was 70. The percentage of the students getting 70 was $22.2 \%$. The causes of the lack of this grammar competence can be from the students and the teacher. Matas and Natolo (2010: 371) state that teaching grammar needs student-centered methods. One of the student-centered methods is PBL. That was why PBL was implemented in this research.

This research was generally to know whether PBL could improve the grammar competence in the fifth semester students of English department of education faculty of Hasyim Asy'ari University (UNHASY) Tebuireng Jombang in the academic year of 2016/2017. It was specifically to describe the lecturer's activities, the students' activities, and the students' responses when PBL was implemented in the grammar class.

\section{Previous Studies}

Several former researchers have conducted previous studies presenting the data which became the proof of the success of PBL in enhancing students' abilities. Othman and Shah (2013: 125) in their research entitled "Problem-Based Learning in the English Language Classroom" found that the post writing test of the students taught by using PBL method got improvement, especially the support and argument of their essay became larger than before. Next, Aziz, Zain, Samsudin, and Saleh (2014: 126) in their research entitled "The Effects of Problem-Based Learning on Self-Directed Learning Skills among Physics Undergraduates” conclude that they did not find the significant differences between PBL and PBL with lecture method, meaning PBL without or with lecture method could improve self-directed learning skills better than the conventional one. The research entitled "Does Problem-Based Learning Improve Problem Solving Skills? A Study among Business Undergraduates at Malaysian Premier Technical University" by Kadir, Abdullah, Anthony, Saleh, and Kamarulzaman (2015: 166) found that students' problem solving abilities got improvement by the use of PBL. Then, Keong and Mohammed (2015: 87) in their research entitled "Improving Iraqi Secondary Students' Speaking Performance through Problem Based Learning Approach" conclude that students' speaking ability and motivation got improvement. Furthermore, 
Dastgeer and Afzal (2015: 1315) in their research entitled" Improving English Writing Skill: A Case of Problem Based Learning" found that PBL was more effective than conventional lecture method to improve secondary level students' writing skill.

\section{Grammar}

Grammar contains a lot of rules of forming words and sentences starting from simple rules up to complex rules. It is supported by Tuan and Doan (2010: 61) who define grammar as the language rules consisting of how to construct and form the words. Meanwhile, Hartwell in Alduais (2013: 38) presents the definitions of grammar as follows: (1) a set of formal patterns in which the words are arranged in order to convey larger meanings, (2) a branch of linguistic science concerned with the description analysis and formulization of formal language patterns, (3) etiquette grammar, (4) common schools of grammar, internalized grammar, and (5) stylistic grammar. Then, McClure in Alduais (203: 38) states that there are four kinds of grammar, such as teachers' or schools' grammar, phrase structure grammar, transformational generative grammar, and cognitive grammar.

\section{Problem Based Learning}

Problem based learning is one of the teaching methods which are student- centered and the teacher becomes a facilitator. It is supported by Etherington (2011: 54) who states that problem-based learning is a student-centered method of teaching in which the students get the duty o solve the real problems related to their materials. Meanwhile, Keiziah (2010: 126) argues that PBL is an innovative teaching method in which the students solve the learning problems in small group and then, they work independently. In line with this statement, Simone (2014: 18) explains that in PBL the learners have collaborative work in analyzing the complex problems and independent work in resuming the problem solving.

According to Othman and Shah (2013: 128), here are the procedures of PBL. The students are grouped into teams of four students, then given a problem on the first day of each new task and expected to present their findings to the class in the following week. After that, the students do the presentations and make a written report that must be submitted to the teacher a few days after all the presentations of a task are done. Dahlan in Rohim (2014: 2-3) presents the procedures of problem-based learning (PBL) as follows: (1) the teacher gives problems to be discussed, (2) the teacher divides the students into pairs, (3) the teacher gives guided questions in order that the students know how to solve the problems, (4) the students discuss with their pairs, (5) the teacher gives time for each pair to express their idea, (6) If 
time is over, the position of asker or answerer has to be changed, and (7) the teacher asks students to retell the result of discussion to class randomly. Next, Dastgeer and Afzal (2015: 1316) give the procedures of PBL as follows: (1) in the first meeting, the class is divided in small groups of 4-5 each and the problems to be discussed and solved are told to the students, (2) in the second meeting, the students clarify and make the focus for finding the solutions, and (3) in the third meeting, the students share and discuss as well as debate the solutions to make final solution in the groups and followed by having written agreement of final solutions with the whole class.

\section{RESEARCH METHOD}

This research was a collaborative classroom action research consisting of four main steps. They were planning the action, implementing the action, observing the action, and reflecting the action. In this research, the researcher was the lecturer of grammar class, especially advanced English grammar. A Semester of Teaching Learning Planning (RPS) of grammar for the fifth semester and blank forms of observation sheets were given to the collaborator. The observation sheets were in the form of field notes which were used to report everything related to the lecturer's activities, students' activities, and students' responses when the lecturer implemented PBL in grammar class. There were two cycles with two meetings of each cycle in this research. Meanwhile, the subjects of the research were 9 students of the fifth semester of English department of education faculty in the academic year of 2016/2017, Hasyim Asy’ari University (UNHASY) Tebuireng Jombang.

\section{Techniques of Collecting Data and Data Analysis}

Observation and the post-test of grammar were the techniques of collecting data in this research. Observation was done by the collaborator by writing all the things which happened in the class in every meeting of the cycle. Meanwhile, the post-test of grammar was held in the following meeting after the second meeting of every cycle. This research used descriptive data analysis and statistical data analysis. The descriptive data analysis gained from the observation data. This data told about the lecturer's activities, the students' activities, and the students' responses during teaching and learning process using PBL. Then, the statistical data analysis was got from the score of the post-test of grammar. This score showed the improvement of the students' grammar competence and the percentage of the students who could pass the minimum criteria mastery. The mean score of pre-test, post test I, and post test 
II were compared to know the improvement of the students' grammar competence. Then, it was consulted to the computational result of SPSS t-test to know whether or not the improvement of the mean scores was significant. It used SPSS version 20. Meanwhile, the minimum mastery criteria was 70 . When $75 \%$ of the students got score 70 became the criteria of the success of this research.

\section{DISCUSSION}

\section{Cycle One}

Cycle one had two meetings. The first meeting was held in November 8, 2016. Then, the second meeting was in November 15, 2016.

\section{A. The Lecturer's Activities}

In the first meeting and the second meeting of cycle one, basically the lecturer did the same activities. As usual she always does every day, she always checks the attendance list at first after opening the class by greeting. Something different from her usual activities was that she told the students that she would use the PBL method to teach grammar class. After that, she did the procedures of PBL. Below were the descriptions of this.

a. The lecturer gave the problems to be solved by the students ( the problems were about the definition of Noun Clause and its examples in the form of reading text in the first meeting and The usages of Noun clause in the sentences and the examples in the form of reading text in the second meeting)

b. The lecturer grouped the students into three groups

c. The lecturer gave guided questions about the definitions of noun clause, the usages of noun clause in the sentences and the real examples of noun clause in the reading text

d. The students discussed with their groups

e. The lecturer asked one of the groups to present the result of their discussion to the class randomly

f. The lecturer gave the corrections of the students' explanation in front of the class.

In the first and the second meetings, the lecturer was walking around the class to check the students' activeness in doing what she instructed. She did not give the exact time when the students had to finish their discussion. It seemed that she only used their feelings when to stop discussion and asked the representative of the group pointed to present the result of their discussion in front of the class. She also did not give the time limitation for the students to 
present the result of their discussion. That was why she only had little time to review the result of the presentations and the students did not have enough time to ask more explanation from the lecturer.

\section{B. The Students' Activities}

Here are the descriptions of what the students did in the first and the second meeting of cycle one.

a. The students sit in group of three

b. The students discussed about the definition of noun clause and the examples in the form of reading text for the first meeting and the usages of noun clause in the sentences and the examples in the form of reading text for the second meeting

c. The students found the information needed from internet and other sources

d. The pointed group presented the result of their discussions in front of the class while other students asked questions about what they did not know.

In the first meeting of this cycle, there was one group that seemed did not seriously do what the lecturer instructed. They made a joke one another while keeping looking at their laptop. They were pointed by the lecturer to present the result of their discussion. Then, they admitted that they were doing the assignments from another lecturer. After that, other group came forward to change the first group pointed. This group told the result of their discussion until the end.

In the second meeting, all of the groups paid full attention to their duty. Unfortunately, there was one student coming late. He directly joined their group to do the instructions from the lecturer with their group. When the lecturer pointed one of the groups to present their result of their discussion, there was one student asking permission to go to the bathroom. It did not disturb the class at all. The discussion could run well.

The following day after the second meeting was the meeting for post-test I. It was held in. The mean score from this test was 66.7 . Only $44.4 \%$ of the students could pass the minimum mastery criteria. That is why cycle one was considered unsuccessful.

\section{The Students' Responses}

The students seemed comfortable with PBL method that was applied by the lecturer since the first meeting of cycle one. They gave positive responses by following what the lecturer requested. Only one group was known not to do their duty well. They told the lecturer honestly that they did the assignment from other lecturer. But other groups were active and 
serious to find the solutions of the problems given by the lecturer. At the end of the class, they asked the lecturer about what grammar books were good for their references. The lecturer suggested using every grammar book and the important point was that they could understand the explanation from that book.

Then, in the second meeting, all of the students were serious in doing discussions and finding the solutions of their discussion problems. All of them brought grammar books that they had. It was not the same as in the first meeting when all of the students only counted on the internet to find the solutions. At the end of the class, some of the students told the lecturer that they still found difficulty in applying their grammar when writing. The lecturer, absolutely, gave suggestion to write everything everyday by considering the rules of grammar they had learned.

\section{Cycle Two}

Cycle two also had two meetings. The first meeting was held in November 22, 2016. Then, the second meeting was in November 29, 2016.

\section{A. The Lecturer's Activities}

What the lecturer did in the first meeting and the second meeting of cycle two was generally the same as what she did in cycle one. The differences were about the problems given to the students and the time limitation for discussion section and presentation of the discussion result. When cycle one, there was no exact time limitation. It was because she seemed to use their feelings only when stopping discussion and presentation. There was no exact time contract. But it was different when cycle two. The lecturer gave the students the exact time for discussion and presentation. It was thirty minutes for discussion and thirty minutes for presentation including questioning and answering in the presentation section.

The procedures of PBL in cycle two were as follows.

a. The lecturer gave the problems to be solved by the students ( the problems were about the definition of coordinating conjunctions and its examples in the form of reading text in the first meeting and kinds of coordinating conjunctions and its examples in the form of reading text in the second meeting)

b. The lecturer grouped the students into three groups

c. The lecturer gave guided questions about the definitions of coordinating conjunction, kinds of coordinating conjunctions, and the real examples of gerund in the reading text

d. The students discussed with their groups in thirty minutes 
e. The lecturer asked one of the groups to present the result of their discussion to the class randomly (time for presentation was thirty minutes)

f. The lecturer gave the corrections of the students' explanation in front of the class.

B. The Students' Activities

Here are the descriptions of what the students did in the first and the second meeting of cycle two.

a. The students sit in group of three

b. The students discussed about the definitions of coordinating conjunctions and the examples in the form of reading text for the first meeting and kinds of coordinating conjunctions and the examples in the form of reading text for the second meeting (time for discussion was thirty minutes)

c. The students found the information needed from internet and the grammar books they brought

d. The pointed group presented the result of their discussions in front of the class while other students asked questions about what they did not know (time for presentation was also thirty minutes)

Both in the first meeting and the second meeting of cycle two, all of the students in their groups did serious effort to do their task based on the problems given by the lecturer. In the first meeting, there was one group raising a hand to present their result of discussion before the lecturer pointed one of the groups. Of course, the lecturer gave the chance to come forward while reminding that the time was thirty minutes for them in front of the class. Their presentation was great. They presented reading text containing what they do everyday. The text was not taken from internet anymore but they wrote the text by themselves by applying the patterns of noun clause and coordinating conjunctions they just learned.

In the second meeting, every group divided the duty for every member. Then, they discussed what they got to solve the problems given by the lecturer. Fortunately, all the three groups wanted to present their discussion result. Finally, the lecturer asked them to do the lottery. The presentation was excellent. The explanation was complete and the reading text was from their real life.

The following day after the second meeting was the meeting for post-test II. It was held in November 30, 2016. The mean score from this test was 72.8. $88.9 \%$ of the students 
could pass the minimum mastery criteria. That is why it can be said that cycle two was considered successful.

C. The Students' Responses

All the students were very comfortable with PBL method that was applied by the lecturer. All of them were full of motivations to join the grammar class. It was proven when the time for presentation in the second meeting came, all of the groups wanted to present their discussion result. They were more active. It could be seen that there was no student coming late anymore. No students wanted to leave the class before the time was really over.

\section{DISCUSSION}

Teaching grammar by using problem-based learning improved not only students' grammar competence but also students' speaking skill as well as students' writing skill. When the students were discussing grammar problems given by the lecturer, they tried to speak as clearly as possible to explain their ideas about their solutions to their friends. This condition was interchangeably done by them in the case of giving questions and answers. It also happened when they were presenting their discussion result in front of the class. They also tried to use the appropriate grammar when asking and answering questions. Al-Mekhlafi and Nagaratnam (2011: 71) state that when grammar is seen as a resource, it can help communication. All of us know that the forms of communication can be oral and written. That is why the activities that the students did in their grammar class also could improve their writing skill. It could be seen from the reading texts that they themselves made. They were strongly motivated to make the reading texts without copying from the internet anymore. They enjoyed learning and applying their grammar lesson in their writing reading texts. Asgari (2013: 488) states that the increasing of students' motivation will effect on the learning improvement. That is what happened when students did what the lecturer instructed in their grammar class.

\section{CONCLUSIONS}

Based on the result of the research, the conclusions can be explained as follows:

1. Problem-based learning could improve grammar competence in the fifth semester students of English department of education faculty of Hasyim Asy'ari University (UNHASY) Tebuireng Jombang in the academic year of 2016/2017. 
2. In cycle one, the lecturer's activities was following the procedures of problem-based learning that she planned. She walked around the class when the students discussed. There was something less in cycle one. She only used her feelings to stop the time for discussion and presentation without telling the students the exact time. Then, she gave the time limitation in cycle two after getting information from the observer. The time for discussion was thirty minutes as well as the presentation.

3. The students' activities in cycle one and cycle two were basically the same. In cycle one, there was one group who did the assignment from another lecturer. So that they did not pay full attention to their discussion. In cycle two, all of the students were active in joining the discussion and also the presentation. All of the groups wanted to present their discussion result in the second meeting of cycle two. But finally, the lecturer made a lottery to choose the group presenting their discussion result. Besides, all of the groups presented their discussion result, made their own reading text without searching from internet or other sources. Their mean score was 66.7 in cycle one and 72.8 in cycle two. Then, $44.4 \%$ of students passed the minimum mastery criteria in cycle one and $88.9 \%$ of students passed the minimum mastery criteria in cycle two. It means that there was an improvement of their grammar competence.

4. The students' responses were good since cycle one. Even though some of them said that they still got difficulty in applying their grammar in their daily life. In cycle two, the students were more motivated to join the grammar class. It was little different between cycle one and cycle two.

From the conclusions above, it could be seen that grammar was learned more interestingly by using PBL. This study found something different from the previous studies using PBL. The finding was that the increase of the students' grammar competence was in line with the increase of their speaking skill and their writing skill. It was because PBL applied in this grammar class gave the opportunities to the students to speak and write more and more. Then, the students seemed to compete in making the better writing and to speak more in presenting their ideas related to the problems of the grammar materials given by the lecturer. Besides, their motivation to learn also had a role in the success of their grammar achievements. 


\section{REFERENCES}

Alduais, A. M. S. (2013). Main schools of grammar, grammar in schools and pedagogical grammar. International Journal of English Language Education, 1(1), 35-48. doi:10.5296/ijele.v1i1.2720

Al-Mekhlafi, A. M. \& Nagaratnam,R. P. (2011). Difficulties in teaching and learning grammar in an EFL context. International Journal of Instruction, 4(2), 69-92.

Asgari, M. (2013). Using current issues of interest in teaching grammar. International Research Journal of Applied and Basic Sciences, 4 (2), 487-495.

Aziz, M. S., Zain, A. N. M., Samsudin, M. A. B, \& Saleh, S. B. (2014). The effects of problem-based learning on self-directed learning skills among physics undergraduates. International Journal of Academic Research in Progressive Education and Development, 3(1), 126-137. doi: 10.6007/IJARPED/v3-i1/694

Baleghizadeh, S. \& Mozaheb, M. A. (2011) A profile of an effective EFL grammar teacher. Journal of Language Teaching and Research, 2(2), 364-369. doi: 10.4304/j1tr.2.2.364-369

Dastgeer, G. \& Afzal, M. T. (2015). Improving English writing skill: A case of problem based learning. American Journal of Educational Research, 3(10), 1315-1319. doi:10.12691/education-3-10-17

Etherington, M. B. (2011). Investigative primary science: a problem-based learning approach. Australian Journal of Teacher Education, 36(9), 53-74. htp://dx.doi.org/10.14221/ajte.2011v36n9.2

Kadir, Z. A., Abdullah, N. H., Anthony, E., Salleh, B. M., \& Kamarulzaman, R. (2015). Does problem-based learning improve problem solving skills? A study among business undergraduates at Malaysian premier technical university. International Education Studies, 9(5), 166-172. doi:10.5539/ies.v9n5p16

Keiziah, A. A. (2010). A comparative study of problem-based and lecture-based learning in secondary school students' motivation to learn science. International Journal of Science and Technology Education Research, 1(6), 126-131.

Keong,Y. C. \& Mohammed, A. H. (2015). Improving Iraqi secondary students' speaking performance through problem based learning approach. International Journal of Education and Research, 3(12), 87-96. 
Lawrence, A. J. \& Lawrence, A. S. A. (2013). Attitude of student teachers towards using grammar games for teaching English. International Journal on New Trends in Education and Their Implications, 4(1), 65-72.

Mart, C. T. (2013). Teaching grammar in context: why and how? Journal of Theory and Practice in Language Studies, 3(1), 124-129. doi: 10.4304/tpls.3.1.124-129

Matas, C.P. \& Natolo, M. (2010). Love grammar: student-driven grammar learning games. The International Journal of Learning, 17(10), 371-381.

Othman, N. \& Shah, M. I. A. (2015). Problem-based learning in the English language classroom. Journal of English Language Teaching, 6(3), 125-134. doi:10.5539/elt.v6n3p125

Priya, S. P. (2015). The importance of teaching grammar more interestingly in the classrooms. International Journal of English Language, Literature and Translation Studies (IJELR), 2(3), 447-449.

Rohim, A. (2014). Improving students' speaking skill through problem based learning (PBL) strategy. $J P 3,3(8), 1-7$.

Simone, C. D. (2014). Problem-based learning in teacher education: trajectories of change. International Journal of Humanities and Social Science, 4(12), 17-29.

Tomakin, E. (2014). Teaching English tenses (grammar) in the Turkish texts: a case of simple Present tense: Iş1 maketi iter. International Journal of Learning \& Development, 4(1), 115-131. doi:10.5296/ijld.v4i1.5154

Tuan, L. T. \& Doan, N. T. M. (2010). Teaching English grammar through games. Journal of Studies in Literature and Language, 1(7), 61-75.

Uibu, K. \& Liiver, M. (2015). Students' grammar mistakes and effective teaching strategies. International Journal of Teaching and Education, 3(1), 70-87. doi:10.204.72/TE.2015.3.1.006 